\title{
Organizing: An Islamic Perspective
}

\section{Md Golam Mohiuddin ${ }^{1}$, Gaffar Olanrewaju Yusof ${ }^{2}$, Afroza Bulbul ${ }^{3}$}

${ }^{1}$ Associate Professor, Faculty of Management and HRD, University Technology Malaysia, Malaysia

${ }^{2}$ Faculty of Management and HRD, University Technology Malaysia, Malaysia

${ }^{3}$ Assistant Professor of Management, Department of Business Administration, IIUC, Bangladesh

\begin{abstract}
The issue of organizing and orderliness is paramount in Islam, it connotes an act of placing things in its proper place which is otherwise known as Hikmah (wisdom) in Islamic term. Today many organization exist, but are not aware of the act of organizing, according to Islamic perspective. Some people equate some Muslims or Islamic NGOs with the true Islamic act of governing this could be misconception on their part. Hence this study wishes to elucidate on act or organizing according to the injunctions of Allah and the practice of the holy prophet. This study employs documentary/library research method and data were collected through both primary and secondary sources. It is found from the study that Islam has its own perfect way of carrying out its organizational function as exemplified by the holy prophet which aims at improving the quality of life and the welfare of the society. It is now the hopes of all nations to direct attention to the way Islam portrayed organizational management and have a fruitful goal in this world and the hereafter.
\end{abstract}

Key word: Organizing, Specialization, Islamic consultation, Delegated authority, Accountability

\section{JEL Classification Code: M12; M54}

\section{INTRODUCTION}

Organizing is a process of identifying and grouping works to be performed, defining and delegating responsibility, authority and establishing relationship for the purpose of enabling people to work effectively together in accomplishing the desired objectives.

There are many management thinkers who have contributed to the study of organizations in many ways. The classical theorists are F. W Tayler (1927), Henry Fayol (1929) and Islamic thinker Abbas J. Ali (2005) who studied various aspects of organizations and developed many management principles that might be interested to learner. The origin of the theory that brings about the issue of organizational structure, is a German Writter named MaxWeber (1974) who wrote about the idea of Burucrracy. The issue of organizing is not only restricted to this world alone, it is also has something to do with the hereafter. That is why Allah mentioned in the holy Quran thus-

$O$ you who believe! Obey God and obey the Messenger and those from among you who are in charge of your affairs; and if you differ over any matter, refer it to God and the Messenger, if you do believe in God and the last day." (Al-quran 4:59) 
If we ponder on the hadith one will see how Allah organizes the sentences, in an orderly manner and thereafter, emphasize the issue of leadership, whose responsibilty is to organize and manage the affairs of poeple, (Ahmad Shaffat, 1984).

Islam is a universal religion followed by over one billion people living in different geopolitical systems and of various professions. The need for knowledge in Islam especially applicable within an organisational setting is increasingly becoming more important. Applied in any organization, Islam stresses co-operation and a sense of collective efforts of people in a working, situation should aimed at achieving a certain goal. Since organizations are composed of very distinct people, with each and everyone of unique character contributing in particular ways based on the culture of unity in diversity.

\section{ISLAMIC Dimention Of Organizing}

Organizing is one of the basic function of management or administration it involves the practical, ordered, and step by step way of implementing a program, project, events etc. This term is used differently by poeple, the usage is largely influenced by the area of specialization of the user. Robert and Judy (2002), state that organizing entails the giving of tasks, the grouping and sorting of tasks into departments and the allocation of resources to departments. Organizing also involves creating communication flow between leader and the leads within the organization. However the basic idea of organizing is to arrange things, or event in order to follow a mannner so that the set goals or objectives could be achieved. In order to get clearer picture of the concept, one need to explain the basic functions of Organizing and its principles .

\section{Basic Functions and Principles of Organizing}

A manager performs organizing function with the help of following steps:
(a) Identification of Activities;
(b) Departmentation the Activities;
(c) Classification the authority;
(d) Co-ordination;
(e) Effective Administration;
(f) Growth \& Diversification;
(g) Sense of Security;
(h) Scope of new changes.

\section{Principles of Organizing}

The organizing process can be done efficiently if the managers have certain guidelines so that they can take decisions and can act. To organize in an effective manner, the following principles of organizations can be used by a manager:
(a) Principle of Specialization;
(b) Principle of Functional Definition;
(c) Principle of Span of Supervision and Control;
(d) Nerrow Span of Control;
(e) Principle of Scalar Chains;
(f) Principle of Unity of Command;

\section{Classification of Organizations}

Organizations are basically classified on the basis of relationships. There are five types of organizations formed on the basis of relationships in an organization:
(a) Formal Organization;
(b) Informal Organization;
(c) Line Organization; 
(d) Line \& Staff Organization;

(e) Functional Organization;

Abbas. J. Ali (2005), stated that organization Structuring was already established by prophet Mohamad (S.A.W) during the early years of Islam. In the history of state philosophy, the Islamic state established at Madina by the Holy Prophet (S.A.W) was a unique example of division of labours. For the proper executionand direction of administrative activities, planning and executive, integration of the competency and it ensure the effective patronization in every field, the strong parliament of Madina was organized through the process of Labour Division. In that Partiament, the name of 24 divisions was detected. For example president's personal division, sealing division, Wahy (Revelation Division) Composing division, reception division, defence division etc. To acquire competency in these divisions, sub-divisions were moduled. The organization structure as can be seen on the figure bellow was very simple and flexible since all officers, regardless of their level in the organization, had the right to approach the prophet or his deputies and report their problems. But as for the expansion of Islamic state across borders of geographical regions, the organization structure became more complex and the authority lines became clearer.

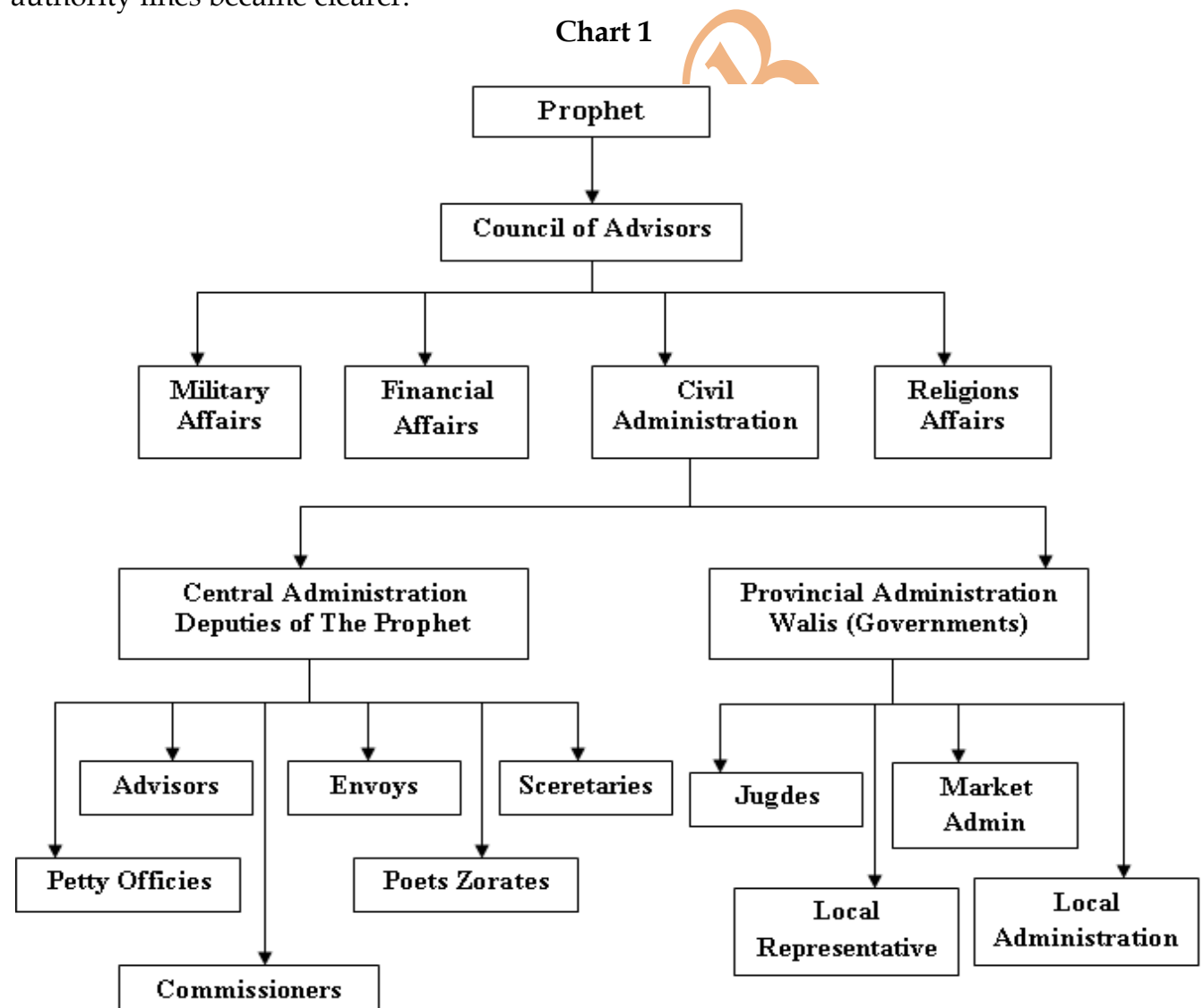




\section{Some Discussions on Different Types of Organizations}

The evolution of formal structure of organizations in Muslim World resembles that of the rest of the world. The nature of the evalution, however, has been influenced by two factor: Sudden and rapid integration in the world economy and the religious emphasis on maintaining order. Unlike Britain or the United States, for example, most Muslim States have not passed through a gradual economic progress and integration on the world after building sound economic and legal institutions. Their involvement in the world economy was introduced mostly by colonization and the exploitation of their natural resources by Western Corporations, while organization structure existed but was not formally drawn. Most of the organizational charts were structured according to functional departmentalization, product on geographical divisional structure existed but were not that common and the mixture of functional and divisional structure were the second most popular structure after functional organization.

About line and staff organization, specialized and supportive activities are attached to the line of command by appointing staff supervisors and staff specialists who are attached to the line authority. The power of command always remains with the line executives and staff supervisors fields, advice and councelling in the line executives. We find numerous examples about the line and staff types of organizational practice during the time of prophet Muhammad (S.A.W) as well in Chalaphat.

It appears that Muhammad (S.A.W) practised Shura in the battle of Ditch (Khandaq) the whole strategy of war was adopted on the suggession of Salman Al-Farisi, who was being Persian freed slave would never have been enjoyed the ordinary rights of citizenship in the pre-Islamic polity.

Summing up, it must be observed that from the very inception of the Islamic Polity, Muhammad (S.A.W) set up the precedent of consulting Muslims generally and a few men having acumen in the religions, economics, social and political affairs of the state in particular. Actually it was the precedent established by the prophet of consulting men of supreme wisdom that played a very significant role on the legal and political development of Islam after the demise of Muhammad (S.A.W).

It has been recorded in the annals of Islam that whenever Abu Bakar had to make a decision, he looked forward to the Quran in the absence of clear nass (textual injunction) in the Quran, he used to refer to the Sunnah and Tradition of the Prophet (S.A.W). But if that failed, then he used to consult the members of the Shura. Regarding the Shura or Staffs of Abu Bakar (R.A) we have the following report from Ibn Sad: "Whenever some important problems were brought to Abu Bakar, he called on the Muhajirin and Ansar and invited 'Umar' in particular, Ali, Uthman, Abu Ubaydah, Abdur Rahman bin Auf, Muadh bin Jabal, Ubayy bin Kab and Zaid bin Thabit for Consultation. It is the example of line line \& staff types of Organization.

Here it is mentionable that during the golden ruling of Umar (R.A), Hazral Ali (R.A) was working with him as close advisor or staff. In numerous cases, it was found that Amirul Mominun Hazral Umar (R.A) had taken very stiff decisions, but some times considering the surroundings these verdict were wrong which are drawn attention by Hazral Ali (R.A) as a staff member and Umar's decisions were corrected by his companion Ali (R.A). Thus once Hazral Umar (R.A) Commented "If Ali (R.A) was not available, Umar (R.A) would destroyed/spoiled". 


\section{DELEGATION OF AUTHORITY}

A manager alone cannot perform all the tasks assigned to him, in order to meet the targets, the manager should delegate authority. Delegation of authority means division of authority and powers down wards to the subordinates. Delegation in about entrusting someone to do parts of your jobs. Delegation of authority can be defined as subdivision and sub-allocation of powers to the subordinates in order to achieve effective results. Islam Underlines the three main aspects:

- Authority

- Responsibility and

- Accountability

Islam has unitary view of life (an off-shoot) of Tawheed as an inter-connected and homogenous which clearly contradicts the secular view that sees life as an intricate mechanism of materialism, therefore in many cases Islam views things against western views base on the fact that the Islamic worldview is different from the west. As result we need to look at how Islam views the above concepts.

\section{Authority}

In context of a business organization, authority can be defined as the power and right of a person to use and allocate the resources efficiently to take decisions and to give orders so as to achieve the organizational objectives.

Now a days, many Muslim-Owned Corporations base their organization structures on some factors ranging from strategy, to type and nature of business and management that is able to manage its stakeholders relationship is likely to gain greater success. Many studies have been conducted on the management and organizational style of "Umar-Bin Khattab (Jabnann, 2001) which was successful due to his well defined relationship among members of his team, discipline of members and mutual respect among themselves. Howeverthis secular world view as adopted by secular nations in the West has a great influence on the organizational culture. They have for a long time prized highly the technical skills requirement and largely ignored the interpersonal relationships in the organization.

Organizing from an Islamic perspective should emphasize the fair relationship within and outside the organization. There are internal stakeholders, such as the managers and employees, as well as external stakeholders such as the customers, community, and government. Islam underlines the three main aspects: Authority, responsibility and accountability in defining these relationships which are elaborated to further study is of high importance due to two fundamental reasons. The establishment of this administration was very successful;

(a) He was the most outstanding person in terms of his religions practice after the prophet (S.A.W) and Abu Bakar, and nobody would accuse him of "Compromising" his faith and discipline;

Generally, he delegated his authority to governors or the officials, by applying the basic principles of decentralization. Probably, more notably important, would be the fact that he was quite happy to incorporate useful concepts/institutions/technology borrowed from non-Muslims. In his administration, the King of Persion used to have a "Ministry of Finance", Umar borrowed this idea and introduced it in Medina to handle the financial affairs of the Umah, there was also an understanding at this time that his administration would benefit from changes in the economic and social environment. In some cases, 
Umar(RA) changes some rulings that were made by prophet (S.A.W) him self, not due to disobedience, but to find a fit to changes in the environment.

About the booties that were received from the land that had been conquered in war was to distributed among those who fought in Jihad. But for better decision, Umar (R.A) gathered a Shura and invited more people than usual. It proves to consider in this context would be the difference between the level of authority (which rests at the top) and power (which needs to be shared with subordinates.

The Islamic perspective on authority encompasses with the classical view and the acceptance view. In fact, the two views can not be mutually exclusive. The term authority has not been used in Islamic materials. Instead, Islam uses the term "Incharge". Islam emphasized discipline and obedience. Allah (S.W.t) Said- "Oh you who believe! Obey Allah and obey the messenger; and those in charge among you." Sura Nisa(4:59).

Authority in Islam in limited within the framework of the mission of Muslims and the interest of the organization. Besides, authority is balanced by the process of enjoining what in right and forbidding what is wrong. It is the duty of subordinates rather than their right not to comply with orders that flagrantly contradict the mission and objectives of Islam or those of the organization. It is also to be understood that the leader should only give feasible and beneficial orders. Most importantly, the nature and scope of complainer should be agreed upon in the job contract, or the job description, and then both the manager and the subordinate have to abide by the contract: "And fulfill (every) engagement, for every angagement will be enquired into on the day of Reckoning". Sura Bani Israil(17:34).

\section{Responsibility}

Responsibility means the obligation owed by subordinates to their superiors for exercising authority delegated to them in a way to accomplish results expected. In Islam every body is responsible. Fox example, a teacher has the responsibility for teaching the assigned subject to his/her students and to test them on it. On the other hard, the students are expected to gain knowledge in their courses and to do their assignments, and are thus ressponsible for these duties. Prophet Said "Behold! Each one of you is a gardian and each one of you will be asked about his subject." ( Bukhari \& Muslim).

Corporate management is difficult when there are unfair and biased dealings with the many stakeholders and non seems to bother about organizational resposibilities. In Islam, mas'uuliyah solves this problem. The term mas'uuliyah (responsibility) is not mentioned as such in the Holy Quran, although a large number of the epistemological derivations of the verb sa'ala may be found. Amanah was mentioned by the most high, as one of the attributes of the angels, of Gabriel, the trustworthy Spirit, and of the Apostles and the Prophets:

"I am to you an apostle worthy of all trust" Al Quran(26:107).

As human being are the vicegerents of Allah, certainly a huge responsibility he has assumed. Allah (SWT) said:

"Lo! we offered the trust into the havenes and the earth and the hills, but they shrank from learing it and were afraid of it and man assumed it. Lo he had proven a tyrant and an ignorant". Surah Alizab (33:72) 
Ali Abdul Kader states that this trust was nothing more than the responsibility that man decided to undertake because of his freedom of choice and his faculty of intellect. Further, it is the responsibility of people to change their status for the better:

"Lo! Allah Changeth not he condition of a folk until they change that which is in their hearts".

Surah Yousof (12:11)

Infact, most of the time our Muslim brothers \& sisters are not serious up to the level of the obligation to accomplish or the set target, but not everybody possesses the same level of responsibility. Managers have heavier responsibilities than subordinates. Therefore, every manager should feel deeply responsible for whatever under his/her authority, more so, responsibility entails accountability in this world and in the hereafter.

First, a religious aspect which concerns the relationship with the Almighty Allah; second, the worldly aspect which concerns relationship with people and one's society, and a third, internal aspect, which is related to one's conscience and inner self. The three aspects were summed up by the Holy Quran in the following verse:

"O ye who believe! Betray not Allah and His messenger, nor knowledge betray your trust." Al-Quran (8:27)

The last religions scripture, the Holy Quran mentions that everybody have to be accountable on the Day of Judgement and this on the basis of these three aspect: the religious, the worldly and the innermost one. the Most High says - "And Say - "Work (righteourness): Soon will Allah observe your work." Al-Quran

\section{ACCOUNTABILITY}

Accountability means giving explanations for any variance in the actual performance from the expectations set. Being accountable means being innovative as the person will think beyond his scope of Job Accountability. In short, accountability means, being answerable for the result. Accountability cannot be escaped. It arises from responsibility.

In Islam this accountability is two folds. First of all an employee is accountable to almighty Allah (SWT), side by side he in also accountable to his immediate loss. It has been prescribed

"Then shall anyone who has done an atom's weight of good, see it! Any one who has done an atom's weight of evil, shall see it" Sura Zura Zilzal (99:7-8).

One of the famous letter of Ali (R.A) was a letter wrote to his governor Malik Astari about accountability-

"Malik you should never forget if you become their monarch, Khaliq will be your monarch and Allah is even highest supremacy than the Khaliq."

To ensure accountability, Islamic management has attributed two conditions: to ensure autonomy of action and to arrange confidence of all types. Thus, Islam undoubtedly preserves the right of giving accountability. 
The feelings of accountability in the hereafter have played a great role in the success of Muslim leaders throughout history, when Umar Ibnu Abdul Aziz become the Caliph of the Muslim, he followed the prophet's guidance saying:

"It is a responsibility, and it is a source of ignominy and regret in the hereafter".

This feelings of accountability was the major characteristics of Umar Ibn Abdul Aziz who was considered to be the fifth righteous Muslim Caliph, Umar (R.A), the second exercise self control:

"Judge yourselves before you will be Judged and weight your deeds before you will be weighed".

The management of an organization does not necessitated depriving some stakeholders for not being accountable to them in order to benefit another stakeholder. It is now being seriously considered as one of the main goals of an organization in form of collective behaviour of "Social accountability." The prophet says:

"Behold! Each of you is a guardian, and each of you will be asked about his subject". (Bukhari \& Muslim)

\section{Centralization \& Decentralization}

Centralization is said to be a process where the concentration of decision making is in a few hands. All the important decisions and actions at the lower level, all subjects and actions at the lower level are subject to the approval of top management. According to Allen, "Centralization is the systematic and consistent reservation of authority at central point in the organization."

On the other hand, Decentralization is a systematic delegation of authority at all levels of management and in all of the organization. In a centralization process, authority is retained by the top management for taking major decisions and framing policies concerning the whole issue . Rest of the authority may be delegated to the middle level and lower level management. The degree of centralization and decentralization will depend upon the amount of authority delegated to the lowest level. According to Allen, "Decentralization refers to the systemetic effort to delegate to the lowest level of authority except that which can be controlled and exercised at central points.

The hint of the centralization of power can be found in the following verses of the Holy Quran- "When there comes to them some matter touching (public) safety or fear, they divulge it. It they had only refered it to the messenger or to those charged with authority among them, the proper investigators would have known if from them (direct). Al-Quran Sura Nisa(3:83). The issue of centralisation can also be found in the following verses of the holy Quran, Anam verse 57, Kasas 70, Muzzammil verse 9

However on the issue of decentralization there are also some suggested verses from the holy Quran such as Nahl verse 36, Anam verse 19, Fatih verse 28, and Tawbah verse 128 Afrin (2012), asserted that Allah has given some duties and responsibilities with proper authority and guidelines to some angels to serve this universe. For example, Gabrail is authorized and responsible to bring revelation to the selected people by Allah (SWT), Azrail is responsible to take the soul of living beings, Mikail is responsible for the provision for the mankind in the universe, and Israfil is responsible for the blowing of trumpet by the last day. 
From all of the above descriptions it is clear that though Allah (SWT) is solely capable to do all the tasks, He has nominated some angels for performing some tasks and also nominated some people in this earth to convey the messages for Allah to other people.

Again,Prophet (S.A.W) had handed over immense power to his provincial, governors and he would emphasize most of the solution of local problem locally. Even, measures were taken to spend fund of zakat collected locally for relevant locality. But there was providence of state involvement in decision contrary to public welfare.

Afrin (2010) also mentioned that, it is clear that in an organization some power and authority should be centralized and some authority must be delegated to the right people and they must be accountable for their authority and responsibility to the higher authority.

\section{Case Study on Some Islamic Organizations of Developing Muslim POPULATED COUNTRY-BANGLADESH}

\section{Islamic Foundation}

There are so many Islamic Organizations in one of the largest populated Muslim Country - Bangladesh . A Study has already been conducted on Islamic foundation and Islamic NGOs working in Bangladesh. Among the government organizations, Islamic foundation is working with different programs in Bangladesh. By personal interview with the executives and staffs of Islamic foundations it is found that Islamic foundation has to face the following problems:

(a) Lack of proper linkage and coordination among the staffs and officers;

(b) Lack of generating team spirit;

(c) Consultative management is not practiced in making decision;

(d) Officials and Religious Ministry do not show only problem solving attitude;

(e) Top level officials and staffs are sometimes found to participate in political activities. It hampers in smooth running of the activities of Islamic foundation;

(f) Financial constraints is a great problem;

(g) Constrant change of high officials like Directors General of Islamic Foundation is a great problem.

\section{Islami Bank Bangladesh Limited (IBBL)}

Islami Bank Bangladesh Limited is a Joint Venture Public Limited Company engaged in commercial banking business based on Islamic Shari'ah with $58.03 \%$ foreign shareholding having largest branch network (246 Branches \& 30 SME/Krishi Branches i.e. total 276 Branches) among the private sector Banks in Bangladesh. It was established on the 13th March 1983 as the first Islamic Bank in the South East Asia.

It is listed with Dhaka Stock Exchange Ltd. and Chittagong Stock Exchange Ltd. Authorized Capital of the Bank is Tk. 20,000.00 Million (\$244.87 Million) and Paid-up Capital is Tk. 10,007.71 Million (\$122.53 Million) having 60,550 shareholders as on 31st December 2011.

\section{Muslim Aid UK}

Muslim Aid is a UK based international relief and development organization working to alleviate poverty worldwide. The charity says it believes in sustainable, local and practical solutions to empower individuals and strengthen communities.

Muslim Aid is guided by the teachings of Islam and endeavors to tackle poverty and its causes by developing innovative and sustainable solutions that enable individuals and 
their communities to live with dignity and by supporting initiatives that promote economic and social justice. Muslim Aid works with all in need, regardless of their race, religion, gender, nationality or political opinion.

Muslim Aid was founded in 1985 when leading British Muslim organizations joined together to respond to endemic humanitarian crises in Africa. The following year, conflicts in Afghanistan and Palestine and floods in Bangladesh saw Muslim Aid expand its emergency relief operations. Over the past 25 years Muslim Aid has grown from a small office in London to a leading UK NGO, providing relief and development programs in over 70 countries across the globe.

Today, Muslim Aid is tackling the root causes of poverty through education and skills training, economic empowerment, orphan care, women development, water, health care and shelter and construction programs.

Muslim Aid believes that, in order to really help people, the causes, not just the symptoms of poverty must be addressed. By 1994 long-term development projects accounted for almost $50 \%$ of Muslim Aid's relief activity. As well as helping people overcome crises. Muslim Aid provides skills and resources to assist people to move forward to a better life. Muslim Aid works closely with the communities to deliver its programs and remains committed to working in collaboration with all its beneficiaries to ensure that the solutions are not imposed from the outside. All solutions are culturally sensitive, practical and owned by the beneficiaries. They have field offices in 13 countries namely, Bangladesh, Bosnia, Cambodia, The Gambia, Indonesia, Iraq, Jordan, Kenya, Lebanon, Pakistan, Somalia, Sri Lanka.

Muslim Aid's Board of Trustees is comprised of 15 respected members of the Muslim community, ensuring that their work is effective, fully accountable and true to the humanitarian spirit of Islam. To evaluate Muslim Aid projects, their Trustees make personal visits to field offices and partner organisations. Every two years the Board of Trustees elects a Chairman, Vice-Chairman, Secretary, Treasurer and an Executive Committee.

At the London headquarters of Muslim Aid a team of professional staff, headed by Chief Executive Officer, is responsible for the management and the effective running of the organisation.

\section{Muslim Aid in Bangladesh}

It has been working in Bangladesh since 1991 with the commitment of "serving humanity". By responding quickly to emergencies, Muslim Aid provides relief to the victims of natural disasters, war and famine. Muslim Aid also deploys long-term development projects on education, skills training, provision of clean water and healthcare to tackle the root causes of poverty. Bangladesh Field Office of Muslim Aid is now working with 24 international and more than 100 national organizations at 53 districts with over 1200 staffs. It has served around 3 million people since its beginning in the country.

Muslim Aid is a signatory of the International Federation of Red Cross and Red Crescent Societies (IFRC), Code of Conduct of NGO in Disaster Relief, a member of British NGOs for Overseas Development (BOND) and supports the UN Millennium Development Goals (MDG). Livelihood, food security, emergency response and disaster risk reduction are the key priority areas of Muslim Aid with ensuring robust community participation. 


\section{Al Haramine Islamic Faoundation}

This Islamic NGO in working for the religious and socio-economic development in Bangladesh. Al Haramine Islamic Foundation has been working with the following programmes since 1993:

(a) Mosque Construction Program;

(b) Tube-Well Program;

(c) Orphanage Construction Program;

(d) Yatim Support Program;

(e) Qurbane Program;

(f) Emergency Relief Program;

(g) Education Program.

The following managerial as well orgnaizational problems have been observed in this Islamic NGO. These are as followos:

(a) The local officers are dissatisfied due to the presence of all foreigners in the Original Organo Structure.

(b) There are some gaps between the foreigners and the local Bangladesh employees.

(c) Consultative management is absent in this organization.

(d) Directors are playing dictatorship role.

(e) There are some discriminations between the foreigners and Bangladesh executives of some level with regard to salary and other benefits.

(f) It in also observed by personal interview with the local executives that their Job Statisfaction is very low.

However, when talking about organizing in Islam, the task is not only restricted to the Muslim NGO;s alone, the Muslim scholar (Ulema) contributions to the muslim community, thruogh the act of organizing, could not be overlooked without mentioned. Therefore, we shall cite the role of Muslim sclolars through Muslim society in spreading Islam in Indian subcontinent as a case study.

\section{Organizing a Muslim Youth Camp}

It is fact that Islam spread and progressed by Muslim Youth. History proves the first Muslim among the boys is Ali (RA), and then he was only eight years old. When Abu Bakr (RA) embraced Islam he was 36 years old. The second successor of prophet- Hazrat Umar(RA) when he embraced Islam was only 27 year old. One Ashara-e-Mobashira Abdur Rahman Bin Awof (RA) only 17 years old when he was with Prophet Muhammad (SAW).

The most peculiar elements in the way the decision process during the rule of Hazrat Umar(RA) were consultations with the Muslim juveniles and especially the consultation with some of his enemies. Umar (RA) believed that juveniles had sharper with minds that enabled them to give original ideas. The practicability of organizing issues are found at present in some Muslim Youths Camps and some Human Resource Development programs scattered in different areas of the world.

It is a part of every Western youngster's life to go camping either with school or with family and friends over holidays and summer breaks. Unfortunately within the Muslim community, children are often not permitted to attend school camps due to the usually very un-Islamic activities which take place on camping trips. Even camps run by Islamic schools, sometimes fail to maintain proper Islamic conduct and behaviour. What we are left with are a fresh batch of disappointed twines and teens that just picked up one more reason to dislike their religion and envy their not-so-God-conscious friends and classmates. 
Unfortunately, the most that Muslim parents do to make up for their children missing out on such camps entailing "major life experiences", as the youth describe them, is sending the kids off to a one-night sleepover at grandma's house or with the cousins who are still in diapers.

The Panjtan Society Youth Group in Melbourne, Australia, recently organized a very successful camp for the younger members of the community.

\section{CONCLUSION}

Managing an organization is not an easy task. In certain respects it is like managing a family where a multitude of factors have to be considered in ordered to maintain a stable environment. An organization can do many things achieving higher productivity and quality outputs. Islam insists on a proper organization of the society. If through organizations the functions of the society can be carried out in a proper manner, the intention to continuously improve the quality and welfare of society should give more attention to the creation of good quality organizations. Our west intoxicated Muslim organization should remember the following Traditions of the Holy Prophet to keep Islamic culture, manner and distinctness so that we are not alleged as too much secular as well materialistic which are creating different types devastating disasters in globally.

Prophet Said: "Those working under you are your brothers. Those who serve you have been made by God subservient to you'. So whoever has his brother under his control should feed him from what he eats and give him clothes like of which he wears; and do not impose on them task which should be too hard for them, and if you impose on them such task, then help them." (Muslim)

\section{RECOMMENDATIONS}

- As Muslim world is lagging behind the technological advancement as well developing large scale organization, they should apply concentration in small scale organization and simple organo structure.

- To make cordial relationship among the members of Islamic organization, Islamic brotherhood (Ukhuk) concepts must be included in different training and development programs in the organization.

- Organizations may take on a life of their own, but they never exist independently of their cultures. Indeed, the application of ihsan in organization is more likely to produce a distinct form of Organization in line with the dynamics of the global marketplace.

- Developing sound and relevant management theory based on Islamic heritage and remove the isolated patterns of development is mostly essential on distinct structure for enterprises operating in Muslim environment.

- Islamic Organization must follow the tazkiah (Teaching and training) system to develop its member which tightened interrelationships.

- Muslim should follow survey method which is least costly to development of organizing activities, like -setting structure, developing monitoring systems, etc.

- For specific organizational structuring and development steps, case studies are in tune with traditions in Islamic inquiry and through them scholars can build a foundation for Conceptual and theoritical propositions relevant to Muslim culture and environment.

- In the above mention situation organization may minimize their shortcomings through moderate Islamic Knowledge with strong leadership quality.

- For successful organizing, the member of the organization should be well informed about the causes of success stories of secular organizations. 


\section{REFERENCES}

[1] Abbas. J. Ali, (2005). Islamic Perspective on Management and Organization.UK: Edward Elgar Publishing Limited. P-187.

[2] Ahmad. S, (1984). How Islam Want Us to Organize Ourselves? Islamic Perspectives Dorval Moque Lectures and Khutbahs http://www.islamicperspectives.com/Default.htm

[3] Al Habsi, (1998). Islamic Management for Excellence. Kualalumpur:Institute Peken Bagen Minda. p-217.

[4] Islam, M.. N.(1985). Secretariate of great prophet. Dhaka: Nur publications. P.1.

[5] Jabnoun,N.(1994).Islam and management. Kualalampur:IKD publications.P-40.

[6] Khaliq Ahmad, (2010). Management form an Islamic perspective, Kuala Lumpur: Prentice Hall.-114

[7] Khaliq Ahmad, (2010). Management form an Islamic perspective, Kuala Lumpur: Prentice Hall.p - 121

[8] Khaliq Ahmad, (2010). Management form an Islamic perspective, Kuala Lumpur: Prentice Hall.P-4

[9] Mohiuddin, M.G.(1997).Islam and scientific management . Dhaka: Islami Foundation, Patrica. P-179

[10] Mohiuddin, M.G.(2005).Islamicc management . Dhaka: University Grants Commission of Bangladesh.

[11] Robert, H. W., \& Judy Z. K. (2002). Leadership and Management in the Hospitality Industry, American Hotel \&Lodgings Association, Educational Institute

[12] Weihrich, H. \& Koontz, H.(1994).Management-A global perspective. Singapure:Mc Graw Hill.p-114

[13] www.hppt.Olema in Organizing Islam.Com

[14] w.w.w.organizing and Islam.com

[15] w.w.w. organization Funcation.Net.

[16] www.ibbl.com 